\title{
HAMBATAN DAN SOLUSI PEMBELAJARAN JARAK JAUH PADA ERA PANDEMI COVID-19 DI JAWA TENGAH
}

\section{OBSTACLES AND SOLUTIONS OF DISTANCE LEARNING IN THE COVID-19 PANDEMIC ERA IN CENTRAL JAVA}

\author{
Mursid Zuhri dan Arif Sofianto \\ Badan Perencanaan Pembangunan, Penelitian, dan Pengembangan \\ Daerah Provinsi Jawa Tengah \\ Jl. Pamuda No. 127-133 Semarang, Jawa Tengah \\ E-mail: zmursid_2010@yahoo.co.id; 01arifsofianto@gmail.com
}

Naskah diterima tanggal: 06-10-2021 disetujui tanggal: 30-11-2021

\begin{abstract}
Distance learning during the COVID-19 pandemic era requires adjustments and has advantages and disadvantages. This study aims to analyze the barriers and advantages of distance learning and to identify solutions for improving distance learning in the COVID19 pandemic era in Central Java. This descriptive research uses a mixed-method of qualitative and quantitative approach. This research involved 260 informants, from principals, teachers, and parents, and involved 84 principals, 831 teachers, 4,124 parents, and 10,048 students as respondents. The instruments include discussion guides and questionnaires. Qualitative analysis uses interactive models, the quantitative analysis uses descriptive statistics (mean and percentage). The result shows that some students have difficulty accessing the internet because of lack of funding and internet signals, some teachers have difficulty mastering ICT. In addition, learning material delivery is limited, character education is weakened as well as students' integrity. In contrast, distance learning increases competence, efficiency, and learning innovations. To conclude, the problem of distance learning is the lack of facilities, lack of mastery of ICT, data packets, and internet networks. The advantages of it are increasing competence, learning innovation, new methods, and efficiency. The solution of distance learning problem is by increasing teacher capacity, improving curriculum, subsidizing internet access, and seeking innovations such as blended learning systems, learning applications, curriculum adjustments, and finding new learning methods.
\end{abstract}

Keywords: COVID-19, distance learning, education problems

\begin{abstract}
Abstrak: Pembelajaran jarak jauh di masa pandemi COVID-19 memerlukan penyesuaian, serta memiliki kelebihan dan kekurangan. Tujuan penelitian ini ialah menganalisis hambatan dan keuntungan pembelajaran jarak jauh dan mengidentifikasi solusi untuk perbaikan pembelajaran jarak jauh pada era pandemi COVID-19 di Jawa Tengah. Tipe penelitian ini ialah deskriptif, dengan pendekatan mixed method kualitatif dan kuantitatif. Informan sebanyak 260 orang, dari unsur kepala sekolah, guru, dan perwakilan orang tua. Survei melibatkan 84 kepala sekolah, 831 guru, 4.124 orang tua, dan 10.048 siswa. Instrumen penelitian berupa panduan diskusi dan kuesioner. Analisis kualitatif menggunakan model interaktif, analisis kuantitatif menggunakan statistik deskriptif (rerata dan persentase). Hasil penelitian menunjukkan sebagian siswa mengalami kesulitan akses internet karena kurangnya pembiayaan dan sinyal internet, sebagian guru kesulitan penguasaan teknologi. Selain itu, penyampaian materi menjadi terbatas, pendidikan karakter dan integritas siswa menjadi lemah. Di sisi lain, pembelajaran jarak jauh meningkatkan kompetensi, efisiensi waktu, serta inovasi pembelajaran yang atraktif. Kesimpulan penelitian ini adalah masalah pembelajaran jarak jauh adalah kurangnya sarana, kurangnya penguasaan teknologi, paket
\end{abstract}


data, jaringan/sinyal internet. Di sisi lain, kelebihannya adalah peningkatan kompetensi, inovasi pembelajaran, pengenalan metode baru, serta efisiensi. Solusi permasalahan PJJ adalah peningkatan kapasitas guru, perbaikan kurikulum, subsidi akses internet, dan inovasi pembelajaran seperti sistem blended learning, pengembangan aplikasi pembelajaran, penyesuaian kurikulum, dan metode pembelajaran baru.

Kata kunci: COVID-19, pembelajaran jarak jauh, permasalahan pendidikan

\section{PENDAHULUAN}

Kebijakan pembelajaran jarak jauh (PJJ) di era pendemi COVID-19, baik yang dilakukan dengan metode online atau daring (dalam jaringan) maupun offline atau luring (luar jaringan) memunculkan kerentanan. Sebagian guru dan siswa belum siap menerapkannya, sejumlah siswa juga terkendala mengakses teknologi digital dan internet (Aji, 2020). Berbagai upaya telah dilakukan pemerintah, mulai dari bantuan operasional sekolah hingga bantuan kuota internet.

Kendala pembelajaran daring ini dikhawatirkan berimplikasi pada krisis kualitas pendidikan karena siswa tidak optimal menerima materi pelajaran. Berkurangnya kegiatan belajar dan interaksi guru dan siswa berpotensi membuat siswa kehilangan pengalaman belajar (learning loss) dan menurun kemampuan belajarnya. Penggunaan teknologi digital untuk pembelajaran memang membantu menjaga keberlanjutan pendidikan di masa pandemi COVID-19 sekaligus menjaga keamanan siswa dari resiko penularan COVID-19. Di sisi lain, pendidikan harus dibangun dengan interaksi antara guru dan siswa di dalam ruang kelas. Namun ada dilema untuk membuka kembali sekolah tatap muka.

Penelitian Aji (2020) menunjukkan hal yang menghambat pelaksanaan belajar jarak jauh, yang dilakukan dengan daring antara lain: 1) keterbatasan penguasaan teknologi informasi oleh guru dan siswa, 2) sarana dan prasarana yang kurang memadai, 3) akses internet yang terbatas, dan 4) kurang siapnya penyediaan biaya baik siswa maupun guru, misalnya untuk data internet. Studi Purwanto, et al. (2020) menemukan bahwa dampak yang dirasakan siswa ketika belajar di rumah akibat COVID-19 adalah: 1) kurangnya sarana dan prasarana (sarpras) yang memadai (laptop, komputer, smartphone) serta lemahnya jaringan internet, 2) belum memiliki budaya belajar daring sehingga kesulitan menyimak pelajaran dibanding tetap muka, 3) siswa membutuhkan waktu beradaptasi melalui bejalar daring, 4) siswa kehilangan waktu bersosialisasi atau berinteraksi dengan teman dan guru, kehilangan jiwa sosial, serta merasa jenuh berada di rumah.

Hasil penelitian Mustakim (2020) menunjukkan bahwa sebagian besar siswa lebih menyukai pembelajaran tatap muka $(46,6 \%)$, dibanding jarak jauh dengan metode daring $(26,7 \%)$ dan blended atau perpaduan tatap muka dengan jarak jauh dengan daring (26,7\%). Kendala pembelajaran jarak jauh dengan metode daring bagi peserta didik meliputi jaringan internet yang tidak stabil, terlalu banyak tugas, sulit fokus, pulsa kuota terbatas, aplikasi yang rumit, dan lebih senang pembelajaran tatap muka (Mustakim, 2020). Masalah lain pembelajaran daring adalah kualitas pembelajaran yang diberikan oleh guru yang kurang mendalam, maupun daya tangkap siswa yang kurang optimal (Dewi, 2020). Santosa (2020) menunjukkan bahwa guru tidak memberikan penjelasan yang memadai tentang materi pembelajaran dan lebih fokus pada pemberian tugas. Siswa juga mengalami penurunan memori pembelajaran ketika tidak hadir di sekolah (Aji, 2020).

Berdasarkan survei Dinas Pendidikan Provinsi Jawa Tengah, secara umum pelaksanaan PJJ dengan metode daring baru mencapai $20 \%$ - 
25\% dari semua sekolah di Jawa Tengah, dan untuk SMA/SMK mencapai 80\% (Nabila, 2020). Survei lainnya dilakukan oleh Forum Anak Jawa Tengah yang melibatkan 590 pelajar dari 35 Kabupaten/Kota di Jawa Tengah. Menurut Ketua Forum Anak Jawa Tengah (Amelia Adiputri Diansari) bahwa dalam pelaksanaan pembelajaran jarak jauh dengan metode daring, terdapat $20 \%$ - $25 \%$ pelajar yang tidak memiliki akses layanan (Pribadi \& Saubani, 2020).

Kondisi di atas tentu perlu diperhatikan mengingat pendidikan merupakan salah satu pilar utama pembangunan manusia. Indeks Pembangunan Manusia berisi dua indikator pendidikan yaitu Harapan Lama Sekolah (HLS) dan Rata-rata Lama Sekolah (RLS). Angka Harapan Lama Sekolah (HLS) Jawa Tengah selama 10 tahun terakhir selalu meningkat. Pada tahun 2011-2012 tercatat peningkatan 0,21\% tetapi peningkatan antara tahun 2019-2020 hanya sebesar $0.02 \%$. Angka rata-rata lama sekolah (RLS) cenderung semakin baik, tertinggi di tahun 2018-2019 tetapi sedikit menurun di tahun 2019-2020 (Badan Pusat Statistik Jawa Tengah, 2020).

Di sisi lain, PJj dengan metode daring juga memiliki beberapa keuntungan untuk pendidikan. Menurut Kuntarto (2017), kelebihan pembelajaran daring dibandingkan dengan pembelajaran konvensional adalah memberikan pengalaman baru yang lebih menantang. Pembelajaran daring tidak dibatasi ruang dan waktu, tersedia sumber di internet, dan bahan ajar mudah diperbarui, serta meningkatkan kemandirian peserta didik (Waryanto, 2006).

Penjelasan di atas menunjukkan perlunya melakukan kajian terkait PJJ dengan metode daring di masa pandemi COVID-19. Beberapa penelitian sebelumnya lebih banyak menyoroti permasalahan teknis, sedangkan penelitian ini menggali masalah dan keuntungan PJJ, serta menganalisis strategi atau solusi agar pembelajaran menjadi lebih baik.
Berdasarkan permasalahan tersebut, tujuan penelitian ini adalah: 1) menganalisis kendala dan keuntungan PJJ terutama dengan metode daring pada era pandemi COVID-19 di Jawa Tengah dan 2) mengidentifikasi solusi pembelajaran yang lebih berkualitas pada era pandemi COVID-19 di Jawa Tengah.

\section{METODE}

Tipe penelitian ini ialah deskriptif, dilakukan untuk mengetahui keadaan subjek penelitian terkait segala sesuatu tentang subjek tersebut (Arikunto, 2002). Penelitian menggunakan pendekatan utama kualitatif, didukung dengan pendekatan kuantitatif. Penelitian ini termasuk dalam penelitian terapan, karena berorientasi pada aplikasi kebijakan sebagaimana dikemukakan Daniel, et al. (2005), bahwa penelitian terapan merupakan usaha untuk menjawab masalah dengan tujuan praktis dan jelas.

Penelitian ini dilakukan di 13 Cabang Dinas Pendidikan Provinsi Jawa Tengah yang merupakan representasi dari 35 Kabupaten/Kota. Sumber data yang digunakan dalam penelitian ini ialah data primer dari informan melalui Diskusi Kelompok Terpumpun (DKT), dari responden melalui Google Form (daring), serta data sekunder dari berbagai dokumen terkait. Populasi dalam penelitian ini ialah semua sekolah SMA/ MA, SMK, dan SLB baik negeri maupun swasta di Jawa Tengah. Jumlah informan yang terlibat dalam DKT sebanyak 260 orang, berasal dari unsur dinas pendidikan, kepala sekolah, para guru, dan orang tua siswa/komite sekolah di 13 wilayah. Responden yang terlibat dalam survei ini sebanyak 84 kepala sekolah, 831 guru, 4.124 orang tua siswa, dan 10.048 siswa.

Teknik pengumpulan data yang digunakan dalam penelitian ini adalah melalui Diskusi Kelompok Terpumpun (DKT) dari unsur pejabat cabang dinas pendidikan, kepala sekolah, para guru, dan komite/orang tua siswa. Pada setiap cabang dinas, ditentukan 20 informan terdiri 
dari 6-7 sekolah (kepala sekolah, guru, komite/ orang tua) dan cabang dinas pendidikan, sehingga jumlah informan yang terlibat dalam DKT di 13 lokasi sebanyak 260 orang.

Teknik pengumpulan data lainnya adalah pengisian kuesioner terhadap responden kepala sekolah, guru, orang tua siswa, dan siswa. Kuesioner menggunakan metode daring dengan sarana Google Form disebarkan secara merata ke seluruh cabang dinas (13 wilayah cabang dinas) dengan sasaran kepala sekolah, guru, orang tua, dan siswa.

Analisis data kualitatif menggunakan model interaktif sebagaimana dikembangkan oleh Miles dan Huberman, yaitu proses pengumpulan, pengolahan, dan penyajian data ditujukan untuk menghasilkan kesimpulan yang saling terkait (Usman \& Akbar, 2008). Data kuantitatif dianalisis menggunakan teknik statistik deskriptif berupa rerata dan persentase. Penelitian dilakukan selama bulan November dan Desember 2020.

\section{HASIL DAN PEMBAHASAN Hasil}

Berdasarkan data survei, jumlah siswa relatif tidak mengalami penurunan. Pada masa pandemi COVID-19, jumlah siswa tahun ajaran 2019/2020 dibanding dengan tahun 2020/2021 justru mengalami peningkatan di sebagian sekolah. Sebanyak 55\% kepala sekolah menyatakan ada peningkatan jumlah siswa, $12 \%$ kepala sekolah menyatakan jumlah siswa tetap, serta 33\% kepala sekolah menyatakan jumlah siswa mereka mengalami penurunan (SMA/SMK negeri dan swasta). Berdasarkan jenis sekolah, sebagian besar peningkatan jumlah siswa ada di SMA negeri dan SMK negeri. Sekolah swasta baik SMA maupun SMK lebih banyak mengalami penurunan jumlah siswa jika dibandingkan tahun ajaran sebelum pandemi COVID-19.

Sekitar 55\% sekolah (SMA/SMK negeri dan swasta) mengalami peningkatan pendaftaran siswa baru dibanding tahun sebelumnya.
Sebanyak 20,24\% tidak mengalami perubahan, dan sekitar $25 \%$ mengalami penurunan pendaftaran. Beberapa sekolah swasta mengalami penurunan pendaftaran lebih tinggi dibandingkan dengan sekolah negeri.

Terkait angka kelulusan, sebagian mengalami kenaikan, hanya sebagian kecil sekolah yaitu $14,29 \%$ yang mengalami penurunan angka kelulusan. Sebagian besar sekolah memiliki angka kelulusan tetap yaitu $59,52 \%$ dan $26,19 \%$ mengalami kenaikan angka kelulusan. Penurunan angka kelulusan pada beberapa sekolah SMK swasta lebih tinggi dibandingkan dengan SMK negeri maupun SMA negeri dan swasta.

Biaya sumbangan pendidikan pada era pandemi COVID-19 menurun lebih dari $20 \%$ di 33 sekolah sampel $(39,29 \%)$, menurun di bawah $20 \%$ di 12 sekolah (14,29\%), dan tidak mengalami perubahan/tetap pada 34 sekolah $(40,48 \%)$. Di sisi lain, sebagian sekolah menaikkan biaya sumbangan sekolah dengan kenaikan kurang dari $20 \%$ yang terjadi di dua sekolah (2,38\%), dan naik $20 \%$ atau lebih pada tiga sekolah $(3,57 \%)$.

Ketersediaan sarana prasarana PJJ sangat berpengaruh dalam menjalankan proses pembelajaran yang diberikan oleh guru kepada para siswa. Sekolah memiliki tanggung jawab dalam pemenuhan kebutuhan pembelajaran berbasis teknologi. Dari total 84 sekolah, sebanyak $54,12 \%$ kepala sekolah menyatakan bahwa sarana prasarana yang diberikan kepada guru cukup memadai. Sependapat dengan kepala sekolah, 42,96\% guru menyatakan bahwa sarana prasarana yang dimiliki oleh guru dalam PJJ secara daring cukup memadai. Adapun pendapat orang tua, sebanyak 1.383 orang $(33,54 \%)$ menyatakan bahwa sarana dan prasarana mereka kurang memadai, dan 145 orang $(3,52 \%)$ menyatakan sangat kurang. Dari pihak siswa, sebanyak 3.222 siswa $(32,07 \%)$ memandang sarana prasarana guru kurang memadai, dan 499 siswa (4,97\%) menyatakan sarana prasarana guru sangat kurang memadai. 
Penelitian ini menunjukkan bahwa terdapat berbagai kendala dalam pelaksanaan PJJ dengan metode daring pada era pandemi COVID-19 ini. Tabel 1 menunjukkan beberapa kendala utama yaitu kendala teknis seperti perangkat, sinyal/ jaringan, data/kuota, kemudian kendala kurikulum dan kedalaman materi, serta kurangnya pendidikan karakter. Adapun keuntungannya antara lain meningkatnya kompetensi penguasaan teknologi informasi, kreativitas, dan inovasi baru dalam pembelajaran. Sebanyak $39.41 \%$ siswa mengakui mengalami keterbatasan sinyal/jaringan, 16,15\% mengalami keterbatasan kuota/paket data internet, $14,43 \%$ mengatakan terkendala daya serap pelajaran, $12,69 \%$ mengeluhkan pada masa pandemi COVID-19 ini agak menurun, bahkan sebagian lainnya menyatakan sangat menurun dibanding sebelumnya. Sebagian kecil kepala sekolah $(5,88 \%)$, guru $(3,73 \%)$, orang tua $(3,03 \%)$, maupun siswa $(4,36 \%)$ justru menyatakan kualitas PJJ dengan matode daring ini jauh lebih baik dibanding konvensional, sebagaimana digambarkan dalam Tabel 3.

Berdasarkan hasil DKT, teridentifikasi beberapa permasalahan $\mathrm{PJ}$ metode daring di era pandemi COVID-19. Sebagaimana dikemukakan oleh Bp. Bbg (SMA N 2 Temanggung) sebagai berikut.

"Problem PJJ daring adalah kesiapan manusia dan kelengkapannya. Kondisi beragam ada yang paham dengan teknologi informasi, ada

Tabel 1 Kendala Siswa dalam PJj Daring Menurut Orang Tua dan Siswa

\begin{tabular}{|c|c|c|c|c|c|}
\hline \multirow{2}{*}{ No } & \multirow{2}{*}{$\begin{array}{c}\text { Kendala Pembelajaran } \\
\text { Daring }\end{array}$} & \multicolumn{2}{|c|}{ Menurut Orang tua } & \multicolumn{2}{|c|}{ Manurut Siswa } \\
\hline & & Jumlah & $\%$ & Jumlah & $\%$ \\
\hline 1. & Sinyal internet & 2278 & 35,87 & 5433 & 39,41 \\
\hline 2. & Paket data & 815 & 12,83 & 2226 & 16,15 \\
\hline 3. & Daya serap & 820 & 12,91 & 1990 & 14,43 \\
\hline 4. & Materi kurang mendalam & 1158 & 18,24 & 1749 & 12,69 \\
\hline 5. & Banyak tugas & 161 & 2,54 & 743 & 5,39 \\
\hline 6. & Keterbatasan Perangkat & 299 & 4,71 & 587 & 4,26 \\
\hline 7. & Jadwal/waktu berbenturan & 128 & 2,02 & 379 & 2,75 \\
\hline 8. & Bosan/jenuh & 18 & 0,28 & 52 & 0,38 \\
\hline 9. & Tidak ada & 673 & 10,60 & 627 & 4,55 \\
\hline & Total & 6350 & 100 & 13786 & 100 \\
\hline
\end{tabular}

Sumber: data primer (2020)

kurangnya kedalaman materi pembelajaran $5,39 \%$ mengaku terlalu banyak tugas, dan 4,26\% mengaku keterbatasan perangkat (ponsel, laptop, tablet).

Tabel 2 menunjukkan bahwa sebagian guru terkendala dengan keterbatasan sinyal $(32,64 \%)$, keterbatasan sarana dan prasarana $(14,77 \%)$, serta kendala paket data/kuota internet $(12,60 \%)$. Sebagian lainnya juga mengalami kendala penguasaan teknologi $(4,75 \%)$.

Sebagian besar kepala sekolah $(58,82 \%)$, guru $(64,74 \%)$, orang tua $(59,82 \%)$, maupun siswa $(56,03 \%)$ memandang bahwa kualitas PJJ
Tabel 2 Kendala dalam PJJ Daring Menurut Guru

\begin{tabular}{|c|c|c|c|}
\hline No. & $\begin{array}{c}\text { Kendala PJJ Daring } \\
\text { Menurut Guru }\end{array}$ & Jumlah & $\%$ \\
\hline 1. & Sinyal internet & 316 & 32,64 \\
\hline 2. & Sarpras & 143 & 14,77 \\
\hline 3. & Paket data/kuota & 122 & 12,60 \\
\hline 4. & $\begin{array}{l}\text { Penyiapan materi } \\
\text { pembelajaran }\end{array}$ & 102 & 10,54 \\
\hline 5. & Penguasaan teknologi & 46 & 4,75 \\
\hline 6. & Siswa malas, jenuh & 45 & 4,65 \\
\hline 7. & Kendala lainnya & 25 & 2,58 \\
\hline 8. & Tidak ada kendala & 169 & 17,46 \\
\hline & Jumlah & 968 & 100 \\
\hline
\end{tabular}

Sumber: data primer (2020) 
Tabel 3 Pernyataan Responden Tentang Kualitas Pembelajaran Jarak Jauh di Era Pandemi COVID-19 Dibanding Sebelumnya (\%)

\begin{tabular}{|c|c|c|c|c|c|}
\hline & $\begin{array}{l}\text { Kualitas } \\
\text { Pembelajaran }\end{array}$ & Kepala Sekolah & Guru & Orang tua & Siswa \\
\hline 1. & Jauh lebih baik & 5,88 & 3,73 & 3,03 & 4,36 \\
\hline 2. & Agak lebih baik & 3,53 & 3,61 & 5,60 & 7,14 \\
\hline 3. & Relatif sama & 20,00 & 10,71 & 11,11 & 11,43 \\
\hline 4. & Agak menurun & 58,82 & 64,74 & 59,82 & 56,03 \\
\hline 5 & Sangat menurun & 11,76 & 17,21 & 20,44 & 21,05 \\
\hline & Total & 100 & 100 & 100 & 100 \\
\hline
\end{tabular}

yang belum paham dengan teknologi informasi. Oleh karena itu, harus dilakukan berbagai cara yang paling sederhana. Validitas hasil penilaian guru menjadi tanda tanya besar. Hasil pekerjaan di rumah tidak bisa terkontrol, apakah memang itu hasil yang sebenarnya dari siswa, valid, atau tidak. Karakter siswa tidak bisa dipantau secara langsung. Tidak mungkin semua materi tercapai. Daya serap siswa jauh dari pembelajaran tatap muka, dan ada pengurangan waktu belajar."

Tabel 4 menjelaskan bahwa sebagian besar responden baik kepala sekolah $(61,18 \%)$, guru $(58 \%)$, orang tua $(54,39 \%)$, maupun siswa $(48,93 \%)$ juga menyatakan bahwa PJJ dengan metode daring saat ini kurang efektif. Sementara sebagian responden kepala sekolah $(23,53 \%)$, guru $(25,03 \%)$, orang tua $(25,24 \%)$, dan siswa $(31,16 \%)$ menyatakan cukup efektif.

Berbagai kendala serta efektivitas yang menurun dari pembelajaran daring perlu segera disikapi. Para guru memiliki harapan-harapan sebagai solusi pembelajaran yang lebih baik di era pandemi COVID-19. Harapan pertama yaitu sebanyak 19,01\% guru menginginkan segeranya dilakukan pembelajaran tatap muka dengan penerapan protokol kesehatan, harapan kedua sebanyak $13,12 \%$ guru menginginkan adanya sinergi yang baik antara guru, orang tua, dan siswa sehingga pembelajaran tidak mengalami penurunan (Tabel 5).

Sebagian orang tua $(37,13 \%)$ dan siswa $(27,88 \%)$ menginginkan tatap muka segera dimulai. Harapan orang tua dan siswa selanjutnya adalah agar ada perbaikan kualitas pembelajaran, memperdalam materi, dan mengurangi tugas-tugas atau pekerjaan rumah, meningkatkan peran guru, serta evaluasi waktu pembelajaran, sebagaimana ditunjukkan pada Tabel 6.

Sesuai Tabel 6, usulan tatap muka dengan protokol kesehatan paling dominan. Di SMK, kesempatan untuk praktik juga masih terbatas, sehingga kompetensi belum sesuai standar yang ditentukan. Masalah lain disampaikan oleh Guru SMKN 1 Gombong bahwa perlu perawatan peralatan-peralatan yang rusak karena sudah lama tidak digunakan. Oleh karena itu, ia berharap diijinkan pembelajaran tatap muka

Tabel 4 Efektivitas PJJ Metode Daring di Era Pandemi COVID-19

\begin{tabular}{cccccc}
\hline No. & Efektivitas Daring & Kepala Sekolah & Guru & Orang Tua & Siswa \\
\hline 1. & Sangat tidak efektif & 3,53 & 3,37 & 6,35 & 6,67 \\
2. & Tidak efektif & 11,76 & 11,79 & 12,05 & 10,93 \\
3. & Kurang efektif & 61,18 & 58,00 & 54,39 & 48,93 \\
4. & Cukup efektif & 23,53 & 25,03 & 25,24 & 31,16 \\
5. & Sangat efektif & 0,00 & 1,81 & 1,96 & 2,32 \\
\hline \multicolumn{7}{c}{ Total } & 100 & 100 & 100 & 100 \\
\hline
\end{tabular}

Sumber: data primer (2020) 
Tabel 5 Harapan Guru terhadap Pembelajaran di Era Pandemi COVID-19

\begin{tabular}{clcc}
\hline No. & \multicolumn{1}{c}{ Harapan guru } & Jumlah & $\%$ \\
\hline 1. & Segera tatap muka & 158 & 19,01 \\
2. Sinergi (guru, orang tua, siswa) & 109 & 13,12 \\
3. Peningkatan sarpras & 96 & 11,55 \\
4. Peningkatan kompetensi & 90 & 10,83 \\
5. Pemberlakukan Blended learning & 81 & 9,75 \\
(luring \& daring) & & \\
6. Program motovasi ke siswa & 72 & 8,66 \\
7. Peningkatan penguasaan IT & 63 & 7,58 \\
8. Bantuan untuk siswa & 55 & 6,62 \\
9. Perbaikan sistem Pendidikan & 44 & 5,29 \\
10. Perbaikan media belajar & 30 & 3,61 \\
11. Pengembangan aplikasi yang & 24 & 2,89 \\
$\quad$ sesuai & 9 & 1,08 \\
12. Guru lebih diperhatikan & 831 & 100 \\
\hline \multicolumn{2}{l}{ Jumlah }
\end{tabular}

Sumber: data primer (2020)

Tabel 6 Solusi Bagi Perbaikan Pembelajaran menurut Orang Tua dan Siswa

\begin{tabular}{|c|c|c|c|c|c|}
\hline \multirow{2}{*}{ No. } & \multirow{2}{*}{ Solusi Perbaikan } & \multicolumn{2}{|c|}{ Orang tua } & \multicolumn{2}{|c|}{ Siswa } \\
\hline & & Jumlah & $\%$ & Jumlah & $\%$ \\
\hline 1. & Tatap muka & 1561 & 37,13 & 2801 & 27,88 \\
\hline 2. & $\begin{array}{l}\text { Perbaiki materi } \\
\text { pembelajaran }\end{array}$ & 512 & 12,18 & 1405 & 13,98 \\
\hline 3. & Kurangi tugas & 395 & 9,40 & 1309 & 13,03 \\
\hline 4. & Meningkatkan peran guru & 506 & 12,04 & 1148 & 11,43 \\
\hline 5. & Evaluasi jadwal/waktu & 156 & 3,71 & 450 & 4,48 \\
\hline 6. & subsidi kuota & 289 & 6,87 & 764 & 7,60 \\
\hline 7. & perkuat jaringan internet & 148 & 3,52 & 265 & 2,64 \\
\hline 8. & Perbaikan kebijakan & 121 & 2,88 & 148 & 1,47 \\
\hline 9. & Lainnya & 367 & 8,73 & 1397 & 13,90 \\
\hline 10. & Tidak ada usul & 82 & 1,95 & 192 & 1,91 \\
\hline 11. & Tidak tahu & 67 & 1,59 & 169 & 1,68 \\
\hline & Total & 4204 & 100 & 10048 & 100 \\
\hline
\end{tabular}

Sumber: data primer (2020)

untuk praktik. Kepala SMK N 1 Gombong menyatakan bahwa:

"di SMK yang sangat penting adalah pembelajaran produktif karena harus mencoba, praktik harus dilakukan langsung. Harapannya ada regulasi atau solusi baru agar siswa bisa hadir tatap muka untuk praktik atau konsultasi ke sekolah, terutama untuk anak kelas 10 . Pendidikan keterampilan tidak hanya diteorikan, tetapi juga harus merasakan, melakukan, dan menganalisis langsung, sedangkan untuk materi normatif bisa dengan PJJ meskipun tidak sempurna"

Di dalam DKT yang dilakukan di 13 lokasi (melibatkan kepala sekolah, guru, dan komite/ orang tua), sebagian besar guru menyatakan bahwa mereka kehilangan makna sebagai pendidik. Kurangnya interaksi guru dan siswa menjadikan kontrol, pendampingan, dan pendidikan karakter kurang optimal. Di rumah orang tua belum tentu bisa menggantikan peran 
guru. Pendalaman materi sangat kurang karena waktu terbatas dan metode pembelajaran tidak memungkinkan, akhirnya kurikulum nasional tidak tercapai.

Kepala sekolah SMAN 3 Cilacap menyatakan masalah pendidikan di era pandemi COVID-19 adalah kurangnya pendalaman materi dan pendidikan karakter, sebagaimana pernyataan berikut.

"Tujuan pendidikan adalah menciptakan manusia yang utuh. Namun, dalam PJj di era pandemi COVID-19 ini interaksi guru dan siswa terbatas, sehingga kurang ikatan emosional, presensi berjalan. Sejauh mana pemahaman siswa mengikuti pembelajaran sangat sulit pemantauannya, apakah ketika presensi mengikuti sampai akhir pembelajaran. Dari segi materi terbatas, dari segi waktu sangat terbatas, karena hanya bisa dilakukan sebentar. Kualitas pembelajaran di era pandemi secara umum kurang sesuai standar, daya serap siswa dipertanyakan karena waktu sedikit, materi sedikit. Mungkin lebih banyak guru memandang PJJ lebih enak, siswa juga banyak yang lebih senang PJJ. Namun, ada kekhawatiran jika terlalu lama PJJ, pendidikan karakter akan sangat berbeda karena interaksi terbatas, maka PJJ tidak bisa menjamin pendidikan secara utuh."

Di sisi lain, PJJ metode daring di era pandemi COVID-19 juga membawa dampak positif. Kepala
SMKN 1 Gombong menyatakan sebagai berikut. "Sisi positif PJJ daring yaitu ada peningkatan kompetensi guru dan karyawan terutama dari penggunaan media dan teknologi informasi. Sebelumnya tidak ada upaya kuat untuk menguasai teknologi informasi sebagai media pembelajaran. Dalam era pandemi ini guru dan karyawan dipaksa belajar. Sebelumnya ujian daring masih jarang, tetapi sekarang sudah bisa melaksanakan ujian elektronik dengan paperless"

Guru, orang tua, dan siswa juga merasakan adanya keuntungan dari PJJ dengan metode daring ini. Keuntungan yang dirasakan antara lain efisiensi waktu, tenaga, atau biaya, bertambahnya penguasaan teknologi, serta proses belajar lebih efektif.

Menurut guru, keuntungan PJJ dengan metode daring di era pandemi COVID-19 ini antara lain meningkatnya penguasaan teknologi $(33,45 \%)$, efisiensi waktu, biaya, tenaga $(33,09 \%)$, pengenalan metode baru $(14,20 \%)$, dan inovasi pembelajaran (3,85\%). Sementara sebagian kecil guru $(7,7 \%)$ justru menyatakan tidak ada keuntungan (Tabel 7).

Orang tua dan siswa juga merasakan adanya keuntungan dari pembelajaran jarak jauh degan metode daring ini. Sebagian besar orang tua merasakan keuntungan berupa efisiensi waktu, tenaga, atau biaya (33,90\%). Sebagian lainnya merasakan keuntungan bertambahnya

Tabel 7 Keuntungan PJJ di Era Pandemi Menurut Guru

\begin{tabular}{clcc}
\hline No. & $\begin{array}{c}\text { Keuntungan PJJ Daring di Era } \\
\text { Pandemi COVID-19 }\end{array}$ & Jumlah & \multicolumn{2}{l}{$\%$} \\
\hline 1. & Penguasan teknologi & 278 & 33,45 \\
2. & Efisiensi waktu/ tenaga/biaya & 275 & 33,09 \\
3. & Pengenalan metode baru & 118 & 14,20 \\
4. Inovasi pembelajaran & 32 & 3,85 \\
5. Memudahkan pembelajaran & 32 & 3,85 \\
6. Kemajuan lainnya & 32 & 3,85 \\
7. & Tidak ada kemajuan & 64 & 7,70 \\
\hline \multicolumn{4}{c}{ Jumlah } \\
\hline
\end{tabular}

Sumber: data primer (2020) 
penguasaan teknologi siswa $(27,45 \%)$, serta proses belajar lebih efektif (4,39\%). Menurut siswa, keuntungan PJJ daring antara lain efisiensi waktu, tenaga, biaya (43,75\%), belajar lebih efektif $(21,91 \%)$, dan penguasaan teknologi $(17,50 \%)$. Meskipun demikian, ada sebagian orang tua $(29,11 \%)$ dan siswa $(11,78 \%)$ menyatakan tidak ada kemajuan sama sekali dari proses ini (Tabel 8).

Berbagai solusi dan inovasi telah dilakukan oleh sekolah maupun guru dalam menyikapi situasi tersebut. Pelatihan untuk guru, bantuan/ subsidi untuk siswa, mengembangkan sistem elearning, membuat aplikasi pembelajaran, pengembangan Learning Management System (LMS) sekolah, mengembangkan metode pembelajaran atraktif, kunjungan ke rumah, serta memulai tatap muka terbatas sudah dilakukan.

Sebagai contoh, di SMKN Juwiring sebagaimana dikemukakan salah seorang guru (YD) terkait aplikasi telah sepakat menentukan platform aplikasi yaitu e learning yang diintegrasikan dengan laman sekolah sehingga aksesnya lebih ringan. Sistem ini dapat digunakan untuk penyampaian materi, ujian, ulangan, penilaian, dan penyampaian informasi. Sebagaimana disampaikan oleh guru SMKN Juwiring lainnya (WY) bahwa mereka menggunakan gabungan e-learning dan campuran berbagai aplikasi. Aplikasi sekolah digabungkan dengan aplikasi lain seperti Google Form untuk presensi, sedangkan materi tersambung ke
Youtube. Mereka juga memiliki ruang di Youtube, yang berisi data semua guru dan materi masingmasing yang bisa diunduh siswa. Mereka juga akan mengembangkan aplikasi yang terintegrasi dan menyeluruh.

Berdasarkan penjelasan di atas, ada kebutuhan tatap muka tetapi masih dibatasi. Di sisi lain ada keuntungan pembelajaran jarak jauh dengan metode daring. Salah satu solusi pembelajaran di era pandemi COVID-19 ini menurut para guru dan siswa adalah penerapan blended learning. Untuk siswa yang terkendala pembelajaran daring, diberikan kesempatan mengikuti pola pembelajaran luring (luar jaringan). Sebagian sekolah meminta siswa yang terkendala daring untuk hadir ke sekolah mengambil materi dan tugas serta menyerahkan kembali hasil pekerjaannya. Sebagian sekolah menerapkan pertemuan atau tatap muka terbatas secara bergantian, dan sebagian lainnya mengikuti pembelajaran daring.

Keyakinan guru terhadap keunggulan blended learning dibanding luring atau daring cukup besar (lihat Tabel 9). Mereka yang menyatakan yakin sebanyak 299 orang (35,98\%), agak yakin 295 orang (35,50\%), sama saja 72 orang $(8,66 \%)$, kurang yakin 155 orang $(18,65 \%)$, dan sangat tidak yakin 10 orang $(1,20 \%)$. Menurut siswa, sangat yakin $(12,59 \%)$ dan yakin $(30,88 \%)$, namun ada juga yang menyatakan kurang yakin $(28,30 \%)$ atau sama saja (26,26\%).

Tabel 8 Keuntungan PJj Daring Menurut Orang Tua dan Siswa

\begin{tabular}{ccrrrr}
\hline \multirow{2}{*}{ No. } & Keuntungan PJj di Era & \multicolumn{3}{c}{ Menurut Orang tua } & \multicolumn{2}{c}{ Manurut Siswa } \\
\cline { 3 - 6 } & Pandemi & Jumlah & \multicolumn{1}{c}{ \% } & Jumlah & \multicolumn{1}{c}{$\%$} \\
\hline 1. & Efisiensi waktu/ tenaga/biaya & 594 & 33,90 & 4396 & 43,75 \\
2. & Penguasan teknologi & 481 & 27,45 & 1758 & 17,50 \\
3. & Belajar lebih efektif & 77 & 4,39 & 2202 & 21,91 \\
4. & Menambah pengetahuan & 46 & 2,63 & 251 & 2,50 \\
5. & Tidak ada kemajuan & 510 & 29,11 & 1184 & 11,78 \\
6. & Tidak tahu & 44 & 2,51 & 257 & 2,56 \\
\hline & Total & 1752 & 100 & 10048 & 100 \\
\hline
\end{tabular}

Sumber: data primer (2020) 
Tabel 9 Tingkat Guru dan Siswa terhadap Keunggulan Blended Learning

\begin{tabular}{clcccc}
\hline \multirow{2}{*}{ No Keunggulan } & \multicolumn{2}{c}{ Menurut Guru } & \multicolumn{2}{c}{ Menurut Siswa } \\
\cline { 2 - 5 } & Blended Learning & Jumlah & $\%$ & Jumlah & $\%$ \\
\hline 1. & Sangat yakin & 299 & 35,98 & 1265 & 12,59 \\
2. & Agak yakin & 295 & 35,50 & 3103 & 30,88 \\
3. & Sama saja & 72 & 8,66 & 2639 & 26,26 \\
4. & Kurang yakin & 155 & 18,65 & 2844 & 28,30 \\
5. & Sangat tidak yakin & 10 & 1,20 & 197 & 1,96 \\
\hline & Jumlah & 831 & 100 & 10048 & 100 \\
\hline
\end{tabular}

Sumber: data primer (2020)

Solusi lain terkait perbaikan pembelajaran di era pandemi COVID-19 adalah pengembangan Learning Management Sysem (LMS) di sekolah untuk memudahkan para guru dan siswa. Berdasarkan hasil survei penelitian ini, sebanyak 495 orang $(60 \%)$ responden guru menginginkan adanya $L M S$ tersebut, sisanya 336 orang (40\%) menyatakan tidak membutuhkan.

Alasan mengapa para guru membutuhkan LMS cukup beragam. Sebanyak 46 persen guru menyatakan bahwa LMS merupakan sarana pembelajaran yang efektif, 26 persen menyatakan memperlancar proses pembelajaran dan 3 persen menyatakan meningkatkan kualitas pembelajaran.

Adapun kriteria $L M S$ yang diinginkan guru yaitu 6 persen guru menginginkan LMS dengan pengembangan sistem daring memanfaatkan aplikasi yang ada (Zoom, Google Classroom, dlI), $10 \%$ menyatakan LMS yang diperlukan adalah yang dapat mendukung pembelajaran, 15\% menyatakan LMS berupa sistem daring menggunakan aplikasi dan data yang ringan, $28 \%$ menyatakan LMS yang dapat berperan memperlancar proses pembelajaran, dan $41 \%$ menyatakan LMS dengan sistem yang mudah digunakan.

\section{Pembahasan}

\section{Kendala dan Keuntungan Pembelajaran Jarak Jauh}

Berdasarkan hasil DKT, isu yang paling menonjol terkait kondisi pendidikan di era pandemi COVID19 adalah kualitas pembelajaran, dalam hal ini efektivitas penyampaian materi dan kurangnya pendidikan karakter. Materi pembelajaran tidak bisa diberikan secara mendalam sebagaimana tatap muka. Terlebih lagi untuk materi pembelajaran di SMK yang seharusnya memerlukan banyak praktik, sedangkan praktik tidak bisa dilakukan secara jarak jauh dengan daring karena keterbatasan alat dan daya serap siswa.

Dari aspek karakter, penanaman nilai-nilai integritas dan pengembangan karakter juga kurang. Kurangnya interaksi sosial antara guru dan siswa serta pengawasan guru terhadap siswa yang lemah menyebabkan pendidikan karakter kurang optimal. Masalah lain adalah ketidaksiapan berbagai pihak, baik sekolah, guru, siswa, dan orang tua untuk menyelenggarakan PJJ daring secara baik. Hal ini dikarenakan sarana prasarana penunjang yang diperlukan belum tersedia dengan baik, serta kendala kapasitas SDM. Menurut guru (sesuai data survei) maupun perwakilan orang tua/komite sekolah yang disampaikan dalam DKT, ada kecenderungan siswa menunjukkan gejala kejenuhan baik karena kurang interaksi, kurang aktivitas, maupun terlalu banyak tugas. Sebagian orang tua siswa juga mengalami kesulitan dalam memfasilitasi siswa baik dalam penyediaan sarana, pembiayaan, maupun pengawasan.

Kendala teknis yang dihadapi siswa antara lain masalah paket data/kuota internet dan keterbatasan perangkat. Kondisi ekonomi keluarga yang kurang menyebabkan pemenuhan untuk belanja kuota atau paket data juga kurang. Masalah teknis lainnya adalah buruknya 
sinyal internet di lokasi tempat tinggalnya, terutama di pedesaan. Salah satu solusi yang dapat dilakukan adalah dengan penyediaan wifi komunitas.

Permasalahan lain adalah terkait dengan efektivitas materi pembelajaran. Para orang tua dan siswa menyoroti masalah sulitnya menerima materi pembelajaran dengan metode daring serta materi yang diberikan juga kurang mendalam. Kendala bagi guru adalah bagaimana mempersiapkan materi pembelajaran yang bisa dikemas melalui media pembelajaran daring tanpa mengurangi kedalaman materi, meskipun dengan keterbatasan waktu dan interaksi. Bagi siswa adalah daya serap yang kurang karena metode atau media yang kurang mudah dipahami. Dengan demikian, pembelajaran di era pandemi ini tidak bisa memenuhi standar sesuai dengan apa yang diterapkan dalam kurikulum.

Kondisi di atas sejalan dengan penelitian Novianto, Herman, dan Hadiapurwa (2021) yang menyatakan bahwa hambatan PJJ berupa kesulitan adaptasi, kurangnya fasilitas perangkat, sinyal, serta kesiapan para pelakunya. Keterlibatan peserta didik, integritas/kejujuran, kemandirian, penguasaan materi, interaksi juga sangat kurang, bahkan memunculkan kerentanan stres dan depresi. Penelitian Panditung, Yuliana, Sukarno, dan Sukino (2020) juga menemukan bahwa beberapa masalah terkait PJJ dengan metode daring pada era pandemi COVID-19 di SMA antara lain pemanfaatan media yang belum maksimal, banyak siswa merasa bosan, kondisi finansial, koneksi internet, dan kedisiplinan siswa.

Selain menghadapi masalah tersebut di atas, proses pembelajaran daring yang menggunakan berbagai media telekomunikasi dan informasi juga membawa beberapa dampak positif bagi guru maupun siswa. Teknologi baru, terutama teknologi informasi mulai dikenal sebagai salah satu media pembelajaran yang atraktif. Berbagai metode pembelajaran baru, mulai dari tatap muka daring, kombinasi pembelajaran luring, menggunakan aplikasi, video, audio, serta animasi. Keuntungan bagi siswa adalah meningkatnya kemampuan teknologi. Siswa berkesempatan untuk belajar dan memahami berbagai aplikasi, media informasi, dan teknologi informasi. Hal ini cukup menguntungkan sebagai bekal untuk bersaing di masa depan. Penelitian Novianto, Herman, dan Hadiapurwa (2021) juga mengungkapkan kelebihan PJJ antara lain lebih fleksibel, kemudahan akses materi, memunculkan pengalaman baru, dan kemudahan evaluasi.

Datangnya pandemi COVID-19 ini menjadi momentum bagi guru untuk mengembangkan berbagai metode pembelajaran yang baru dengan memanfaatkan teknologi informasi. Kemampun guru dalam pembelajaran daring, pemanfaatan multimedia, teknologi informasi dan komunikasi harus terus ditingkatkan dan menjadi bagian dari kompetensi mengajar.

Kesiapan siswa juga perlu menjadi perhatian dalam menguasai teknologi informasi dengan baik. Sebagian siswa belum terbiasa dengan pola pembelajaran (jadwal), disiplin, tanggung jawab, dan integritas. Begitu juga dengan kesiapan orang tua dalam memenuhi sarana dan prasarana, pendampingan, dan pengawasan.

Sekolah telah melakukan berbagai upaya dalam pelaksanaan PJj secara daring, baik berupa sarana prasarana, peningkatan kemampuan, maupun bantuan. Selain berasal dari pemerintah pusat (Kementerian Pendidikan dan Kebudayaan), sekolah juga memberikan bantuan kepada guru dan siswa. Beberapa sekolah juga telah melakukan inovasi dalam perbaikan PJJ ini. Bantuan kepada siswa juga telah diberikan oleh sekolah dengan subsidi paket data/kuota internet. Bantuan Iain diberikan dalam bentuk perangkat: ponsel, tablet, komputer, wifi, maupun berupa uang tunai. Sebagian sekolah juga menggalang dana iuran dari guru untuk membelikan telepon selular bagi siswa yang kurang mampu. Sekolah juga melakukan pelatihan pengenalan teknologi 
informasi untuk pembelajaran dan peningkatan kompetensi guru dalam menyiapkan bahan ajar. Sebagian sekolah juga sudah mengembangkan e-learning dan LMS sesuai dengan kebutuhan mereka.

\section{Solusi Pembelajaran Lebih Baik di Era Pandemi COVID-19}

Pembelajaran jarak jauh memang dianggap tidak seefektif pembelajaran tatap muka. Namun, pilihan ini dianggap tepat di tengah pandemi COVID-19 (Hidayah, 2020). Di sisi lain, segera memberlakukan pembelajaran tatap muka merupakan harapan sebagian besar guru, orang tua, dan siswa. Terkait dengan harapan tersebut, konsep perpaduan pembelajaran tatap muka atau secara luring dan PJJ secara daring menjadi pilihan strategis. Beberapa kelemahan dalam PJj daring bisa ditutup dengan pembelajaran tatap muka. Di sisi lain, beberapa keunggulan dan keuntungan $\mathrm{PJ}$ J secara daring dapat membantu meningkatkan kualitas pembelajaran tatap muka. Oleh sebab itu, model blended learning bisa menjadi pilihan.

Pemerintah daerah dan sekolah perlu mulai merencanakan alokasi penganggaran yang memadai dalam pemenuhan PJJ daring maupun pembelajaran tatap muka sesuai dengan protokol kesehatan. Para guru juga mengharapkan agar mereka lebih diperhatikan. Salah satu upaya yang dilakukan adalah dengan meningkatkan kompetensi mengajar dan kemampuan penguasaan teknologi infomasi dalam pembelajaran. PJJ daring membutuhkan kemampuan penguasaan teknologi informasi. Keberhasilan PJJ daring juga dipengaruhi oleh kualitas sumber daya manusia (Salsabila, Sari, Lathif, Lestari, \& Ayuning , 2020).

Pemenuhan sarana dan prasarana merupakan kebutuhan dasar yang harus dipenuhi. Oleh sebab itu, kebijakan anggaran harus memperhatikan pemenuhan kebutuhan ini. Di tingkat yang lebih tinggi, standar kualitas pendidikan juga perlu dievaluasi dengan memasukkan kebutuhan pemanfaatan teknologi informasi dan pemanfaatan media digital dalam pembelajaran.

Harapan pada tataran kebijakan yang lebih umum adalah perbaikan pada sistem pendidikan, termasuk kurikulum. Responden mengharapkan kebijakan pemerintah untuk penyediaan atau pengembangan media pembelajaran yang lebih baik.

Harapan terhadap perbaikan sistem pendidikan dan inovasi pembelajaran tersebut bermuara kepada pengembangan LMS. Beberapa sekolah telah berusaha mengembangan LMS mereka sendiri, baik dikembangkan dari awal maupun menggunakan basis yang sudah disediakan oleh Kementerian Pendidikan dan Kebudayaan maupun Pemerintah Daerah.

\section{SIMPULAN DAN SARAN}

\section{Simpulan}

Pembelajaran di era pandemi COVID-19 dengan strategi belajar dari rumah secara daring menghadapi masalah kurangnya sarana dan prasarana, penguasaan teknologi, paket kuota/ data, dan jaringan/sinyal internet. Dari pihak siswa, belum terbiasa dengan pola pembelajaran (jadwal), disiplin, tanggung jawab, dan integritas. Dari orang tua siswa, sebagian memiliki kendala kemampuan pemenuhan sarana dan prasarana, pendampingan, serta pengawasan.

Kelebihan belajar dari rumah secara daring yaitu terjadi peningkatan kompetensi guru dan siswa, baik dalam penguasaan teknologi informasi maupun peningkatan pengetahuan, munculnya inovasi pembelajaran, pengenalan metode baru, efisiensi waktu/tenaga/biaya, memudahkan dalam pembelajaran, dan peluang untuk perbaikan materi pembelajaran. Pada awal pandemi COVID-19 banyak guru belum siap menghadapi perubahan metode pembelajaran. Namun, seiring waktu kesiapan guru sudah meningkat dengan berbagai pelatihan. Sekolah juga telah menyiapkan sarana dan prasarana yang memadai serta mendorong inovasi baru. 
Hal-hal yang dibutuhkan untuk mewujudkan pendidikan yang berkualitas yaitu peningkatan kapasitas guru, subsidi sarana dan prasarana, perbaikan sistem pendidikan, inovasi pembelajaran, dan pengembangan aplikasi pembelajaran yang sesuai kebutuhan. Beberapa kebijakan atau inovasi yang dibutuhkan adalah pemberlakuan sistem blended learning untuk mengatasi kendala PJJ dengan metode daring. Sekolah dapat menggunakan metode luring baik dengan kunjungan guru, mengundang siswa yang terkendala daring ke sekolah, atau tatap muka di sekolah secara terbatas terutama untuk jenis mata pelajaran tertentu. Kebijakan lainnya adalah pengembangan LMS baik oleh sekolah maupun pemerintah, penyesuaian kurikulum di era pandemi, dan mendorong berbagai inovasi metode pembelajaran.

\section{Saran}

Untuk pemenuhan sarana dan prasarana (paket data/kuota, jaringan/sinyal) dapat dilakukan dengan kolaborasi berbagai sektor antara lain pemerintah daerah dengan lembaga bisnis, lembaga nonpemerintah, pemerintah desa, atau komunitas masyarakat (RT dan RW) di dalam rangka penyediaan dan penguatan akses jaringan internet gratis melalui fasilitas wifi. Untuk menyikapi kendala penguasan teknologi informasi dapat diantisipasi dengan meningkatkan kapasitas guru. Hal ini dilakukan dengan mengalokasikan lebih banyak dana untuk kegiatan penguatan kapasitas guru, sarana dan prasarana teknologi informasi, serta inovasi. Sebagai solusi perbaikan pembelajaran ialah dengan mendorong sekolah menerapkan sistem blended learning, mengembangkan aplikasi elearning sekolah, serta mendorong penerapan LMS, baik oleh sekolah maupun difasilitasi oleh Dinas Pendidikan.

\section{UCAPAN TERIMA KASIH}

Tim penulis mengucapkan terimakasih kepada segenap pihak yang telah membantu proses penelitian dan tersusunnya artikel ini. Terimakasih disampaikan kepada Kepala Bappeda Provinsi Jawa Tengah, serta kolega para peneliti di Bappeda Provinsi Jawa Tengah yang telah memberikan informasi, saran, dan masukan.

\section{PUSTAKA ACUAN}

Aji, R.H.S. (2020). Dampak COVID-19 pada pendidikan di Indonesia: Sekolah, keterampilan, dan proses pembelajaran. SALAM: Jurnal Sosial dan Budaya Syar-i, 7(5), 395-402. doi: 10.15408/ sjsbs.v7i5.15314

Arikunto, S. (2002) Prosedur penelitian: Suatu pendekatan praktik. Jakarta: Rineka Cipta.

Badan Pusat Statistik Jawa Tengah. (2020). Indeks pembangunan manusia Kabupaten/Kota Jawa Tengah. BPS, (78), 1-10. https://jateng.bps.go.id/

Dewi, W.A.F. (2020). Dampak COVID-19 terhadap implementasi pembelajaran daring di sekolah dasar. Edukatif: Jurnal Ilmu Pendidikan, 2(1), 55-61. doi.org/10.31004/edukatif.v2i1.89

Hidayah, N. (2020). Tantangan kebijakan pembelajaran jarak jauh di era pandemi COVID 19. Jurnal Pencerahan, 14(2), 133-151.

Kuntarto, E. (2017). Keefektifan model pembelajaran daring dalam perkuliahan bahasa Indonesia di Perguruan Tinggi. Journal Indonesian Language Education and Literature, 3(1), 99-110. doi.org/10.24235/ileal.v3i1.1820 
Mustakim. (2020). Efektivitas pembelajaran daring menggunakan media online selama pandemi COVID-19 pada mata pelajaran Matematika. Al asma: Journal of Islamic Education, 2(1), 112. doi.org/10.24252/asma.v2i1.13646

Nabila, M. (2020). Pembelajaran jarak jauh di Jawa Tengah hadapi banyak kendala. semarang.bisnis.com, 14 July. https://semarang.bisnis.com/read/20200714/535/1265731/ pembelajaran-jarak-jauh-di-jawa-tengah-hadapi-banyak-kendala.

Novianto, G.D., Herman, D.A. \& Hadiapurwa, A. (2021). Pelaksanaan pendidikan jarak jauh bagi pendidik dan peserta didik di masa pandemi COVID-19 di sekolah dasar. Jurnal Inovasi Pendidikan dan Pembelajaran Sekolah Dasar, 4. 98-111.

Panditung, A.R., Yuliana, A., Sukarno, \& Sukino. (2020). Implementasi kegiatan pembelajaran jarak jauh era pandemi COVID-19 di tingkat SMA. Jurnal Pendidikan dan Pembelajaran, 5(4), 231240.

Pribadi, B. \& Saubani, A. (2020). Survei: 25 persen pelajar Jateng tanpa akses penunjang PJJ. republika.co.id, 21 July. https://republika.co.id/berita/qdtrny409/survei-25-persen-pelajarjateng-tanpa-akses-penunjang-pjj.

Salsabila, U.H., Sari, L.I., Lathif, K.H., Lestari, A.P., \& Ayuning, A. (2020). Peran teknologi dalam pembelajaran di masa pandemi COVID-19. Al-Mutharahah: Jurnal Penelitian dan Kajian Sosial Keagamaan, 17(2), 188-198. doi.org/10.46781/al-mutharahah.v17i2.138

Santosa, A.B. (2020). Potret pendidikan di tahun pandemi: Dampak COVID-19 terhadap disparitas pendidikan di Indonesia. CSIS Commentaries.

Usman, H. \& Akbar, P.S. (2008). Metodologi Penelitian Sosial. Jakarta: Bumi Aksara.

Waryanto, N.H. (2006). Online learning sebagai salah satu inovasi pembelajaran. Pythagoras: Jurnal Matematika Pendidikan Matematika, 2(1), 10-23. 